\title{
Kelimpahan Bakteri Coliform Pada Air Laut, Sedimen dan Foraminifera Jenis Calcarina Di Ekosistem Terumbu Karang Pulau Pramuka, Kepulauan Seribu, DKI Jakarta
}

\author{
The Abundance of Coliform Bacteria in Sea Water, Sediment and Foraminifera Type \\ Calcarina In Coral Reef Ecosystem of Pramuka Island, Kepulauan Seribu, DKI Jakarta \\ Agus Tri Askar *), Mochamad Untung Kurnia Agung, Yuli Andriani, dan \\ Lintang Permatasari Yuliadi \\ Fakultas Perikanan dan Ilmu Kelautan \\ Universitas Padjadjaran \\ J1. Raya Bandung - Sumedang KM 21 Jatinangor UBR 40600 \\ Email korespondensi : agustriaskar305@gmail.com
}

\begin{abstract}
Abstrak
Bakteri coliform sudah lama dikenal sebagai bioindikator cemaran bahan organik di suatu perairan. Perairan laut merupakan muara bagi semua jenis limbah baik organik maupun anorganik yang berasal dari daratan. Foraminifera yang merupakan diatom bentik yang khas ditemukan di ekosistem terumbu karang juga dapat terkontaminasi bakteri coliform pada perairan yang mengalami kondisi pencemaran bahan organik. Penelitian ini bertujuan untuk mengetahui nilai kelimpahan bakteri coliform pada air laut, sedimen dan foraminifera jenis calcarina. Penelitian ini dilaksanakan dari bulan Maret sampai Agustus 2017 di Laboratorium Mikrobiologi dan Bioteknologi Molekuler (MICROMOL) Fakultas Perikanan dan Ilmu Kelautan (FPIK) Universitas Padjadjaran. Metode yang digunakan pada penelitian ini adalah metode Most Probable Number (MPN) yang dibandingkan dengan standar baku mutu Kep-51/MENKLH/2004. Hasil penelitian menunjukkan bahwa kelimpahan bakteri coliform pada air laut yaitu 9->1100 ${ }^{\mathrm{MPN} / 100} \mathrm{~mL}$, pada sedimen sebesar 7-803,33 ${ }^{\mathrm{MPN} / 100} \mathrm{~g}$ dan yang ditemukan pada foraminifera jenis calcarina berkisar $<3-16^{\mathrm{MPN} / 100} \mathrm{~g}$. Nilai bakteri coliform yang didapat pada sampel sedimen dan foraminifera masih dibawah ambang batas baku mutu Kementrian Lingkugan Hidup Nomor 51 tahun 2004. Namun, Pada sampel air laut hanya stasiun 1 dan stasiun 2 sudah melebihi batas ambang baku mutu yaitu $1100^{\mathrm{MPN} / 100} \mathrm{ml}$.
\end{abstract}

Kata Kunci : Calcarina, Coliform, Foraminifera, Metode MPN

\begin{abstract}
Coliform bacteria has long been known as bioindicator contamination of organic matter in a waters. Marine waters are the end dump for all types of waste both organic and inorganic originating from the mainland. Foraminifera which is a typical benthic diatom found in coral reef ecosystems can also be contaminated with coliform bacteria in organic polluted waters. This research aims to determine the abundance of coliform bacteria in sea water, sediment and also in calcarine foraminifera. The research was conducted from March to August 2017 at the Laboratory of Microbiology and Molecular Biotechnology (MICROMOL), Faculty of Fisheries and Marine Sciences (FPIK) Universitas Padjadjaran. The method used in this research is Most Probable Number (MPN) method compared with Kep-51/MENKLH/2004 as standard of water quality. The results showed that the abundance of coliform found in sea water that is $9->1100^{\mathrm{MPN} / 100} \mathrm{~mL}$, in sediment is $7-803,33^{\mathrm{MPN} / 100} \mathrm{~g}$ and in foraminifera calcarina ranged from $<3-16^{\mathrm{MPN} / 100} \mathrm{~g}$. The value of coliform bacteria obtained in sediment samples and foraminifera is still within the limits of the quality standard of the Ministry of Living Environment No. 51 of 2004. However, in seawater samples only station 1 and station 2 have already exceeded the quality level of 1100 $\mathrm{MPN} / 100 \mathrm{ml}$.
\end{abstract}

Keywords: Calcarine, Coliform Foraminifera, Method of MPN 
Agus Tri Askar : Kelimpahan Bakteri Coliform Pada Air Laut, Sedimen dan Foraminifera Jenis Calcarina Di Ekosistem Terumbu Karang Pulau Pramuka, Kepulauan Seribu, DKI Jakarta

\section{Pendahuluan}

Pulau Pramuka merupakan salah satu pulau yang memiliki kepadatan penduduk yang cukup tinggi dibandingkan dengan pulau di sekitarnya sekaligus sebagai daerah wisata. Tingginya kepadatan penduduk dan banyaknya wisatawan akan menghasilkan buangan limbah organik yang tinggi.

Perairan laut merupakan muara bagi semua jenis limbah baik organik maupun anorganik. Menurut beritapulauseribu.com pada bulan September 2016 sebanyak $20 \mathrm{~kg}$ sampah kiriman dari 13 sungai besar mulai dari muara sungai Cisadane di bagian barat sampai muara sungai Citarum di bagian timur yang bermuara di Teluk Jakarta. Sampah tersebut terbawa oleh arus sampai ke Pulau Pramuka dan menyebabkan terjadinya pencemaran. Perairan tersebut memiliki peran yang sangat penting dalam menopang kehidupan biota serta mendapat ancaman serius untuk terjadinya pencemaran yang berasal dari aktivitas masyarakat. Menurut Salle (2013) aktivitas masyarakat dapat menyebabkan terjadinya pencemaran dan dapat meningkatkan bakteri patogen di perairan sehingga menyebabkan kerusakan pada suatu ekosistem.

Ekosistem terumbu karang memilki multifungsi yang sangat besar bagi berbagai biota laut. Biota laut seperti foraminifera dapat membantu proses pembentukan terumbu karang. Selain berasosiasi dengan terumbu karang, foraminifera juga dapat berasosiasi dengan alga atau diatom (Hallock et al 1991) dan bakteria (Van brugen et al 1983) yang ditemukan pada foraminifera besar (Richardson \& Rutzler 1999) dan foraminifera kecil (Bernhard 2006). Salah satu foraminifea besar adalah jenis calcarina. Calcarina merupakan epifauna yang bersosiasi dengan baik pada terumbu karang (Rositasari 1988). Biota laut pada umumnya terdapat bakteri patogen dan nonpatogen. Bakteri patogen tersebut dapat menyebabkan terganggunya metabolisme pada foraminifera dalam pembentukan cangkang. Keberadaan bakteri patogen dapat disebabkan karena adanya pencemaran limbah organik pada perairan.

Perairan yang tercemar limbah organik dapat dideteksi dengan melihat kelimpahan bakteri coliform pada suatu perairan. Keberadaan bakteri coliform dapat meningkatkan jumlah bakteri patogen seperti
Vibrio chorela, Salmonella, dan Shigella yang berakibat rusaknya cangkang foraminifera yang akan berpengaruh terhadap aktivitas pembentukan terumbu karang. Oleh karena itu, dibutuhkan suatu kajian mengenai keberadaan bakteri coliform pada foraminifera khususnya calcarina.

\section{Bahan dan Metode}

Penelitian ini dilaksanakan pada bulan Maret sampai Agustus 2017. Pengambilan sampel dilakukan di Pulau Pramuka Kab.Kepulauan Seribu, Jakarta. Sampel yang sudah diambil kemudian dianalisis di Laboratorium Mikrobiologi dan Biotekologi Molekuler, Fakultas Perikanan dan Ilmu Kelautan, Universitas Padjadjaran.

Pengambilan sampel dilakukan pada 5 stasiun di Pulau Pramuka. Sampel yang diambil berupa sampel sedimen dan sampel air laut. Sampel sedimen dimasukkan kedalam plastik ziplock sedangkan sampel air laut dimasukkan kedalam botol plastik dan dibungkus menggunakan lakban hitam. Semua sampel kemudian diberi label dan dimasukkan kedalam coolbox. Selain pengambilan sampel sedimen dan air laut, diukur juga parameter fisik lingkungan seperti salinitas, suhu, DO dan $\mathrm{pH}$.

Penentuan jumlah bakteri coliform dilakukan dengan metode Most Probable Number (MPN). Tabung yang berisi medium Lactose Broth yang menunjukkan hasil positif, diambil satu ose kemudian dimasukkan kedalam tabung reaksi yang berisi medium Brilliant Green Lactose Broth (BGLB) dan diinkubasi selama $1 \times 24$ jam pada suhu $37^{\circ} \mathrm{C}$. Kemudian hasil positif dari medium BGLB diinkubasi kedalam medium endo agar pada suhu $37^{\circ} \mathrm{C}$ selama $1 \times 24$ jam. Selanjunya dicocokkan dengan tabel perhitungan MPN.

\section{Hasil dan Pembahasan}

Penentuan distribusi bakteri coliform pada kelima lokasi penelitian yang menggunakan sampel air laut, sedimen dan calcarina dilakukan pengamatan selama 24 jam dengan beberapa tahapan uji menggunakan metode MPN. Pada tahap 1 uji pendugaan dilakukan isolasi bakteri menggunakan medium lactose broth (LB). Medium LB ini digunakan untuk 
menumbuhkan bakteri yang mampu memfermentasi laktosa. Selanjutnya hasil positif dari medium LB dilanjutkan dengan uji tahap II yaitu uji penegasan dengan medium Brilliant Green Lactose Broth (BGLB). Medium ini digunakan untuk menghambat pertumbuhan bakteri gram positif dan gram negatif selain bakteri coliform. Hasil positif dari kedua medium tersebut berupa terbentuknya gas dan medium menjadi keruh. Menurut Sari dan Apridamayanti (2014) terbentuknya gas tersebut disebabkan karena terjadinya proses fermentasi laktosa yang menghasilkan $\mathrm{CO}_{2}$. Setelah itu diambil satu ose bakteri dari medium BGLB yang positif dan diinokulasi kedalam medium endo agar. Hasil yang terbentuk dari medium endo agar adalah terbentuknya koloni berwarna hijau kilat metalik. Menurut Khotimah (2016) Bakteri coliform akan menghasilkan asam dari hasil fermentasi sehingga menghasilkan hijau kilat metalik. Berdasarkan hasil penelitian, maka semua sampel mengandung bakteri coliform (Tabel 1).

Tabel 1. Kelimpahan Bakteri Coliform Pada Semua Sampel

Table 1. Abundance of Coliform Bacteria In All Sample

\begin{tabular}{cclll}
\hline \multirow{2}{*}{ Stasiun } & \multirow{2}{*}{$\begin{array}{c}\text { Air } \\
\text { Laut }\end{array}$} & Sedimen & \multicolumn{2}{c}{ Foraminifera } \\
\cline { 4 - 5 } & & $\begin{array}{l}\text { Kelimpahan } \\
\text { Foraminifera }\end{array}$ & $\begin{array}{l}\text { Kelimpahan } \\
\text { Bakteri }\end{array}$ \\
\hline 1 & 1100 & 783.333 & 97 & 16 \\
2 & $>1100$ & 8.3 & 92 & $<3$ \\
3 & 24 & 12 & 75 & $<3$ \\
4 & 9 & 7 & 87 & $<3$ \\
5 & 150 & 803.33 & 53 & 11 \\
\hline
\end{tabular}

Pada tabel 1 dapat dilihat kelimpahan bakteri pada air laut berkisar antara 9->1100 MPN/100 mL. Jumlah total bakteri coliform pada air laut tertinggi terdapat pada stasiun 1 dan stasiun 2 yaitu nilainya mencapai 1100 dan $>1100$ MPN/100 mL. Tingginya kadar kandungan bakteri coliform pada stasiun 1 dan stasiun 2 diduga dikarenakan adanya kandungan organik yang tinggi diperairan tersebut yang berasal dari aktivitas masyarakat, seperti perdagangan, Pariwisata dan Pelayaran. Menurut Salle (2013) bahwa pembuangan limbah organik yang berasal dari aktivitas masyarakat dapat menyebabkan pencemaran dan dapat meningkatkan organisme patogen di perairan. Menurut Berita harian kompas.com ada sekitar $20 \%$ sampah organik dari total $142,2 \mathrm{~kg}$ sampah yang berasal dari 3 pulau yang ada di Kepulauan Seribu yaitu Pulau Panggang, Pulau Pramuka dan Pulau Kriya. Sampah tersebut berasal dari 13 sungai yang berada di Teluk Jakarta (Folmer 2016), kemudian terbawa arus musim timur beserta mikroorganisme yanga ada di teluk Jakarta ke perairan Pulau Pramuka. Kepadatan bakteri coliform pada Teluk Jakarta berkisar antara 0.9 x $10^{3}-1100 \times 10^{3}$ per $100 \mathrm{ml}$ (Thayib dkk 1994).

Pada stasiun 3, 4 dan 5 memiliki nilai kelimpahan bakteri coliform sebesar 24 MPN/100
$\mathrm{mL}, 9^{\mathrm{MPN} / 100} \mathrm{~mL}$ dan150 ${ }^{\mathrm{MPN} / 100} \mathrm{~mL}$. Nilai tersebut masih berada dibawah ambang atas baku mutu lingkungan. Rendahnya nilai kelimpahan bakteri coliform mungkin disebabkan karena rendahnya kandungan organik yang ada di perairan tersebut serta jauhnya aktivitas manusia dari lokasi penelitian sehingga kelimpahan bakteri tersebut rendah. Nilai tersebut masih dibawah ambang batas baku mutu namun apabila dibiarkan kemungkinan nilai tersebut dapat terus meningkat.

Pada tabel 1, kelimpahan bakteri coliform di sedimen berkisar antara 7-803,33 ${ }^{\mathrm{MPN} / 100} \mathrm{~g}$. Nilai kelimpahan bakteri pada keempat stasiun pada sampel sedimen lebih rendah dibandingkan dengan air laut. Hal ini kemungkinan disebabkan karena adanya resuspensi pada sedimen yang mengakibatkan bakteri yang ada disedimen naik kepermukaan air laut dan menyebabkan tingginya nilai kelimpahan bakteri pada air laut. Resuspensi sedimen tersebut dikarenakan adanya aktivitas kapal pada keempat stasiun. Aktivitas kapal tersebut dapat menimbulkan gelombang yang berakibat terjadinya pengadukan pada perairan. Selain karena pengaruh gelombang oleh aktivitas kapal, resuspensi pada sedimen keempat stasiun juga kemungkinan disebabkan oleh adanya arus. Menurut Satriadi (2012) 
resuspensi sedimen dapat disebabkan oleh gelombang, arus dan pasang surut. Pada stasiun 5 nilai kelimpahan bakteri coliform pada sedimen lebih tinggi dibandingkan dengan air laut. Hal ini disebabkan bakteri yang ada di perairan akan mengendap dilapisan sedimen. Selain iu juga tingginya bakteri di lapisan sedimen kemungkinan tidak terjadinya resuspensi sedimen pada stasiun 5 yang disebabkan oleh jarangnya aktivitas perkapalan yang melintasi pada stasiun tersebut. Keberadaan bakteri coliform pada sedimen sangat berbahaya bagi organisme yang hidupnya sangat bergantung dengan sedimen tersebut seperti siput, ikan dan kerang-kerangan. Keberadaan baketeri coliform dapat menghambat pertumbuhan biota serta dapat menyebabkan penyakit pada manusia yang mengkonsumsi biota yang terpapar bakteri coliform (Sutiknowati 2013).

Keberadaan bakteri coliform pada sedimen memungkinkan adanya keberadaan bakteri coliform pada beberapa organisme yang hidupnya berasosiasi dengan sedimen tersebut. Foraminifera bentik merupakan salah satu organimse yang hidupnya berada pada sediemen yang mana foraminifera tersebut hidupnya juga berasosiasi dengan terumbu karang. Menurut Nybakken \& Bertness (2006) Keberadaan foraminifera yang berasosiasi dengan terumbu karang akan meningkatkan proses kalsifikasi dibandingkan dengan yang tidak berasosiasi dengan foraminifera bentik. Hasil kelimpahan jenis calcarina pada masingmasing stasiun dapat dilihat pada tabel 1. Pada tabel 1, jumlah foraminifera calcarina berkisar antara 53-97 Ind/m2. Dengan adanya foraminifera jenis calcarina pada semua stasiun menandakan bahwa daerah tersebut terdapat ekosistem terumbu karang. Menurut Penelitian Natsir (2010) bahwa ditemukan $72,80 \%$ foraminifera bentik yang berasosiasi dengan terumbu karang terutama dari marga Calcarina, Amphistegina dan Tynoporus.

Pada tabel 1, hasil kelimpahan bakteri coliform pada foraminifera calcarina berkisar antar $<3-16^{\mathrm{MPN} / 100}$ g. kelimpahan tertinggi hanya terdapat pada stasiun 1 dan stasiun 5 yaitu sebesar 16 dan $11^{\mathrm{MPN} / 100}$ g. Adanya bakteri coliform pada kedua stasiun tersebut kemungkinan disebabkan Karena kandungan bakteri coliform pada lapisan sedimen (tabel 1) juga tinggi. Adanya bakteri coliform pada foramifera tersebut bisa menjadi indikasi awal untuk penyebaran bakteri patogen pada foraminifera jenis calcarina. Salah satu bakteri patogen seperti vibrio dapat mengakibatkan pecahnya protein pada dinding sel dengan menggunakan enzim protease sehingga memudahkan penetrasi bakteri ke dalam sel dan merusak jaringan sel pada suatu organisme (Rosenberg et al 2007; Sussman et al 2003). Keberadaan bakteri coliform pada foraminiera diduga terdapat pada aperture dan vacoula. Aperture merupakan mulut yang berfungsi untuk mensekresikan $\mathrm{CaCO}_{3}$ dalam pementukan cangkang foraminifera. Ketika bakteri coliform terdapat didalam aperture akan menganggu metabolisme pembentukan cangkang dan sekresi $\mathrm{CaCO}_{3}$ pada foraminifera tersebut sehingga pembentukan cangkang menjadi tidak sempurna. Foraminifera memiliki ukuran berbeda-beda tergantung dari jenisnya masing-masing. Ukuran foraminifera calcarina berkisar antara 1 mm-3 mm (Renema dan Johann 2005) sedangkan ukuran bakteri e-coli memiliki panjang 2,0 - 6,0 $\mu \mathrm{m}$ dan lebar 1,1-1,5 $\mu \mathrm{m}$. Jadi, memungkinkan keberadaan bakteri pada foraminifera calcarina terdapat pada aperture atau vakuola.

Parameter perairan pulau pramuka masih tergolong baik untuk pertumbuhan bakteri coliform. Suhu pada lokasi penelitian berkisar antara 26,1-30 ${ }^{\circ} \mathrm{C}$. Salinitas pada masingmasing stasiun berkisar antara 28- 31 ppt. Kadar oksigen terlarut yang didapat pada penelitian ini adalah berkisar antara 5,1-6,65 $\mathrm{mg} / \mathrm{L}$. Nilai $\mathrm{pH}$ pada 5 stasiun pengambilan sampel berkisar antara 7.64-8.78.

Perairan Pulau pramuka memiliki karakteristik sedimen jenis pasir,lumpur, dan kerikil. Hasil perolehan analisis fraksi sedimen kerikil berkisar antara 0.88-8.09 \% dengan rata-rata $4.008 \%$. Sedimen pasir untuk masing-masing stasiun merupakan fraksi yang tertinggi berkisar antara 80.77-90.51\% dengan rata-rata seluruh stasiun mencapai $86.54 \%$. Sedimen lumpur berkisar antara 1.10-18.38\% dengan rata-rata $9.88 \%$. Total jumlah sebaran bakeri coliform pada sedimen terbanyak terdapat pada stasiun 1 dan stasiun 5 . Keadaan ini sebanding dengan fraksi sedimen yang diperoleh yaitu pasir berlumpur. Dengan banyaknya kandungan lumpur yang terdapat pada stasiun ini memungkinkan akumulasi bahan organik pada stasiun ini. Dengan kandungan bahan organik yang tinggi akan 
memiliki senyawa karbon organik sebagai sumber makanan bagi bakteri (Aris 2016).

\section{Simpulan}

Berdasarkan hasil penelitian yang telah dilakukan maka kesimpulan yang dapat diambil adalah bakteri coliform ditemukan pada foraminifera dengan kelimpahan $<3-16$ $\mathrm{mpn} / 100 \mathrm{ml}$ serta ditemukan juga pada air laut yaitu 9->1100 mpn/100 $\mathrm{ml}$ dan pada sedimen kisaran rata-rata bakteri coliform yaitu 7$803,33 \mathrm{mpn} / 100 \mathrm{ml}$. Nilai bakteri coliform yang didapat pada sampel sedimen dan foraminifera masih dibawah ambang batas baku mutu Kementrian Lingkugan Hidup Nomor 51 tahun 2004. Namun, pada sampel air laut hanya stasiun 1 dan stasiun 2 sudah melebihi batas ambang baku mutu yaitu 1100 MPN $/ 100 \mathrm{ml}$.

\section{Daftar Pustaka}

Aris, A. 2016. Isolasi dan Identifikasi Bakteri Escherichia Coli Pada Sedimen Di Perairan Teluk Riau Kota Tanjung Pinang. Jurusan Ilmu Kelautan. FIKP UMRAH

Bernhard, J. M., A. Habura., S.S. Bowser. 2006. An Endobiont-bearing allogromiid from the Santa Barbara Basin: Implications For The Early Diversification Of Foraminifera. $J$. Geophysical Res. 110, 1-10

Keputusan Menteri Lingkungan Hidup Bidang Kebijakan dan Kelembagaan Lingkungan Hidup. 2004. Standar Baku Mutu Air Laut Nomor 51 Tahun 2004. Jakarta: Kementerian Lingkungan Hidup RI.

Folmer. 2016. Perairan Pulau Pramuka Dipadati Sampah. www.beritajakarta.id

Hallock, P., Premoli Silva, I. \& Boersma, A. 1991. Similarities between planktonic and larger foraminiferal evolutionary trends through Paleogene paleooceanographic changes. Palaeogeogr. Palaeoclim., Palaeoecol., 83, 49-64

Khotimah, L. 2016. Analisis Cemaran Bakteri Coliform dan Identifikasi Escherichia coli Pada Es Batu Kristal dan Es Balok di Kelurahan Cibubur Jakarta Tahun

2016. Universitas Negeri yarif

Hidayatullah Jakarta. Jurusan Farmasi.

Fakultas Kedokteran Dan Ilmu

Kesehatan

Natsir, S. M. 2010. Foraminifera Bentik

Sebagai Indikator Kondisi Lingkungan

Terumbu Karang Perairan Pulau Kotok

Besar dan Pulau Nirwana, Kepulauan

Seribu. Oseanografi dan Limnologi di

Indonesia, 36(2):181-192

Nybakken J.W. dan M.D. Bertness. 2006.

Marine biology: An ecological

approach. 6th ed. San Fransisco:

Pearson education. Inc. 579p.

Renema, W dan Johann H. 2005. On Identity

Calcarina Spengleri. Journal of

foraminiferal reaseacrh. Vol 35(1): 1521

Richardson, S.L. dan Rutzler, K. 1999.

Bacterial endosymbiots in the

agglutinating foraminiferan

spiculidendreon corallicolum.

Symbuisis, 26 299-312.

Rosenberg, E., Koren, 0., Reshef, L., Efrony, R,, Zilber-Rosenberg, I . 2007. The

Roole of Microorganisms in Coral Health, Disease and Evolution. Nat Rev Microbiologi 5: 355-362.

Rositasari. R. 1988. Calcarina sebagai genus indikator pada lingkungan terumbu karang resen.(B. SITUMORANG ed.) Pros. Simp. IAGI XVII: 79-85

Salle, A.J. 2013. Fundamental Principles of Bacteriology. 8ed. Harper \& Brothers. Studi Pendahuluan Klasifikasi Ukuran Butir Sedimen di Danau Laut Tawar, Takengon, Kabupaten Aceh Tengah, Provinsi Aceh. Banda Aceh: Universitas Syiah Kuala. Volume. 92-96 No. 2. ISSN 2089-7790

Sari, R dan P Apridamayanti. 2014. Cemaran Bakteri Coliform Escheria Coli Dalam Beberapa Makanan Laut Yang Beredar Di Pasar Tradisional Kota Pontianak. Kartika Jurnal Ilmiah Farmasi. No.2(2) Hal 14-19.

Satriadi, A. 2012. Analisis Sebaran Sedimen Tersuspensi Di Perairan Paciran Lamongan Jawa Timur. Buletin Oseanografi Marina. Vol 1. 13-30 hlm.

Sutiknowati, L Indah. 2013. Kualitas Air yang Mendukung Potensi Budidaya di Perairan Pesisir Pulau Pari: Aspek Mikrobiologi. Jakarta:Pusat Penelitian 
Agus Tri Askar : Kelimpahan Bakteri Coliform Pada Air Laut, Sedimen dan Foraminifera Jenis Calcarina Di Ekosistem Terumbu Karang Pulau Pramuka, Kepulauan Seribu, DKI Jakarta

Oseanografi - LIPI. Jurnal Segara Vol 8 No. 2 Desember 2012: 65-75.

Sussman M, Loya Y, Fine , M. Rosenberg E (2003). The Marine Fire Worm hermodicekaruunculatais a winter reservoir and spring summer vector for the coral Bleaching pathogen Vibrio Shiloi. environ Microbiol 5:250-255
Thayib, Soeminarti S., Yeti D dan Ruyitno. 1994. Dampak Aktivitas Manusia Pada Mikroflora di Teluk Jakarta. Seminar Pemantauan Pencemaran Laut. Jakarta.

Van Bruggen, John J,A., Claudius K,Stumm., dan Godfried D, V. 1983. Symbiosis of Methanogenic Bacteria and Sapropelic Protozoa.Arch Microbiol, 136:89-95 